\title{
Industrial symbiosis as an element of sustainable development of arctic companies
}

\author{
Sergei Nikonorov ${ }^{1, *}$, and Ekaterina Utkina $^{1}$ \\ ${ }^{1}$ Moscow State University, GSP-1, 1-46 Leninskiye Gory, Moscow, 119991, Russia
}

\begin{abstract}
Economic activity in the Arctic is playing an increasingly important role in the globalizing economy, given that such an economy is largely based on natural resources (oil, gas and minerals) as well as the long-distance transport of these resources and related goods. The Arctic seems to be one of the last opportunities to exploit vast resources, which, ironically, made it possible by the negative effects of this very exploitation in the form of global warming and the subsequent retreat of the ice cover of the circumpolar North. Thus, the Arctic has already become and will continue to be part of economic globalization. The article gives an analysis of the dynamics of the «Polar Index of the Barents region. Companies». The need to include the main elements of industrial safety in the sustainable development of the Arctic has been justified, as well as the establishment of industrial symbiotic cooperation rating based on it. Industrial symbiosis is an economically efficient and environmentally friendly solution for industry that reduces energy consumption and primary material consumption by deriving value from waste, byproducts and heat losses.
\end{abstract}

\section{Introduction}

Despite significant advances in public understanding and awareness of sustainable development, the economic component of sustainability has traditionally prevailed, with states and individual firms working first. However, the traditional mode of economic development cannot guarantee the sustainable development of the Russian economy, and a scientific approach is needed to effectively correct the entire economic system. The development of the regional economy of the Russian Arctic is inseparable from the concept of sustainable development. The new economic system needs innovation from the top down, including the diversion of investment into new areas, the emergence of new markets for "green" industry and the acceleration of regional economic transformation. The management of environmental problems in our country has been ineffective for many years. The reason lies in the varying degree and dynamics of development of different regions. Economic development cannot ignore environmental costs and attempt to replace the necessary costs of environmental transformation with support for exceptionally highspeed economic development.

In 2020, a number of important strategic and longterm planning documents were adopted, defining the State policy for the development of the Arctic for the next 15 years. Among the most significant ones are the State Policy Framework for the Arctic Zone 2035 and the Strategy for the Development of the Arctic Zone of the Russian Federation and for National Security 2035.
The Ambitious List of Infrastructure Projects was set out in the Strategy, On the one hand, it shows the leading role of Russia in the Arctic, and on the other hand it is intended to give a signal to business representatives, attracting them to participate actively in the investment of these facilities. At the same time, efforts to improve the activities of the federal authorities in the development of the Arctic were continued: the composition of the State Commission on Arctic Development was renewed, and its powers expanded; the newly formed Ministry of the Russian Federation for the Development of the Far East began its activities.

The State Policy Framework for the Arctic Zone 2035 and the Strategy for the Development of the Arctic Zone of the Russian Federation formulate and refine the Russian State policy in the Arctic in the context of medium- and long-term planning and could become the basis for the program of the Russian Federation's presidency of the Arctic Council for the period 2021-2023. The authors suggest that the future program should include themes of concern to the region, centred on its sustainable development with a balanced mix of environmental, economic and social components. These include improving the quality of life and living conditions of people in the Arctic, adapting to climate change; preserving fragile Arctic ecosystems and biodiversity while developing the region's economy, large-scale extractive and processing projects, Intensification of freight traffic on

\footnotetext{
*Corresponding author: nico.73@mail.ru
} 
the Northern Sea Route. Addressing these challenges requires the collective efforts of all Arctic Council members and the development of new approaches to international cooperation.

The ambitious list of infrastructure projects set out in the Strategy shows, on the one hand, Russia's leading role in the Arctic, and, on the other hand, it is intended to send a signal to business representatives, encouraging them to participate actively in the investment of these facilities. The State Commission for the Development of the Arctic should constantly monitor the implementation of the established tasks.

\section{Ranking methodology and dynamics}

In order to correct the existing imbalance in the categories of stability of regions and companies, the Polar Index rating (hereinafter - the Rating) was created, which is a complex multi-level model for assessing sustainable development from the internal level, at which the companies of the region are located, to the external, regional level, where the sustainability of the region itself is assessed from the standpoint of the state, society and business.

The rating "Polar Index of the Barents Region", presented for the first time at the end of 2018, is the result of reaching the international level, developed earlier by the rating "Polar Index. Regions and Companies" aimed at assessing the sustainable development of regions and companies in the Russian Arctic. The indicators in the ratings taken in three key areas of sustainable development (ecology, economy and social) are updated annually.
The following indicators are used to calculate the Barents index:

- Economic. The basis of the indicator is the financial performance of companies according to international financial reporting standards.

- Social. The basis of the indicator is the quality of corporate responsibility (CSR) reporting.

- Environmental. The basis of the indicator is the qualitative characteristics of environmental management systems.

The Arctic companies reviewed in the Ranking are largely represented by the extractive sector, which has a strong impact on sustainability. Extractive industries are often characterized as energy-intensive and resource-intensive, with significant greenhouse gas emissions and high resource dependence [3] which makes it a good target for the implementation of new strategies and methods to improve resource and energy efficiency.

In the updated Rating of 2020, in terms of companies' research, the listed categories are represented as the vertices of a triangle (Fig. 1), in which companies are the core, while the vertices are mutually dependent on each other [1]. The outer vertices of the triangle are represented by government, business and society. Government, divided into federal, regional and local levels, is defined as measures taken by the authorities or administrations of the region to support, regulate and ensure the interaction of business and society. Businesses are large, medium and small operating enterprises operating in the study area. Accordingly, society is the sum total of all citizens of a given country, region or locality.

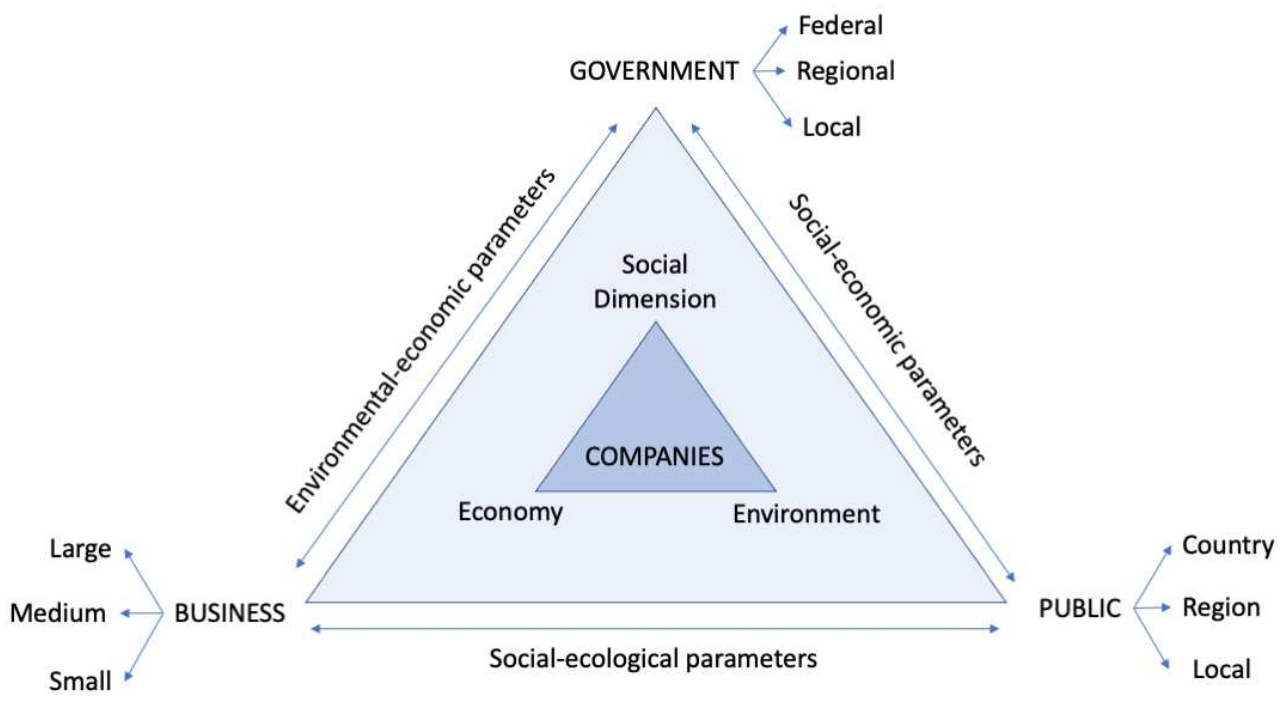

Fig. 1. Conceptual approach to the compilation of the Polar Index. 
Table 1. Results of the Barents-Region Polar Index rating calculation. Companies

\begin{tabular}{|c|c|c|c|c|c|c|}
\hline № & Company & Country & & $\begin{array}{c}\text { Polar Index } \\
2018\end{array}$ & $\begin{array}{l}\text { Polar Index } \\
2019\end{array}$ & $\begin{array}{c}\text { Changing } \\
\text { Rating } \\
\text { Position } \\
\end{array}$ \\
\hline 1 & Rosneft & Russia & & 8,51 & 9,00 & $\uparrow 1$ \\
\hline 2 & Lukoil & Russia & & 8,01 & 8,33 & $\uparrow 2$ \\
\hline 3 & Equinor & Norway & & 9,00 & 8,00 & $\downarrow_{2}$ \\
\hline 4 & Norilsk Nickel & Russia & & 7,62 & 7,67 & $\uparrow 3$ \\
\hline 5 & LKAB & Sweden & & 6,01 & 7,67 & $\uparrow 9$ \\
\hline 6 & $\begin{array}{ll}\text { First } & \text { Quantum } \\
\text { Minerals } & \end{array}$ & Finland & & 4,00 & 7,67 & $\uparrow 14$ \\
\hline 7 & Agnico Eagle Mines & Finland & & 7,65 & 7,67 & $\downarrow 1$ \\
\hline 8 & ALROSA & Russia & & 8,01 & 7,33 & $\downarrow 5$ \\
\hline 9 & Gold Fields & Finland & & - & 7,00 & New \\
\hline 10 & Phos Agro & Russia & & 7,31 & 6,67 & $\downarrow 1$ \\
\hline 11 & Petoro & Norway & & - & 6,67 & New \\
\hline 12 & Novatek & Russia & & - & 6,33 & New \\
\hline 13 & Gazprom & Russia & & 6,65 & 6,33 & 0 \\
\hline 14 & Boliden Group & $\begin{array}{l}\text { Finland } \\
\text { Sweden }\end{array}$ & l & 7,67 & 6,00 & $\downarrow 9$ \\
\hline 15 & Nordic Mining & Norway & & 7,14 & 6,00 & $\downarrow 4$ \\
\hline 16 & RUSAL & Russia & & 2,72 & 5,67 & $\uparrow 10$ \\
\hline 17 & Magnus Minerals & Finland & & - & 5,67 & New \\
\hline 18 & Severstal & Russia & & 7,28 & 5,67 & $\downarrow 8$ \\
\hline 19 & Sydvaranger Gruve & Norway & & 5,99 & 5,67 & $\downarrow_{4}$ \\
\hline 20 & Concedo & Norway & & 5,95 & 5,00 & $\downarrow_{4}$ \\
\hline 21 & $\begin{array}{l}\text { Leonhard Nilsen \& } \\
\text { Sonner }\end{array}$ & Norway & & 5,66 & 5,00 & $\downarrow 4$ \\
\hline 22 & Dragon Mining & Sweden & & 5,21 & 4,33 & $\downarrow 3$ \\
\hline 23 & $\begin{array}{ll}\text { Norge } & \text { Mineral } \\
\text { Resources } & \end{array}$ & Norway & & 5,33 & 4,00 & $\downarrow 5$ \\
\hline 24 & Beowulf Mining & $\begin{array}{l}\text { Finland } \\
\text { Sweden }\end{array}$ & l & 3,37 & 3,00 & 0 \\
\hline 25 & Nussir & Norway & & 3,64 & 2,33 & $\downarrow 3$ \\
\hline 26 & $\begin{array}{l}\text { Aurion Resources } \\
\text { Ltd. }\end{array}$ & Finland & & 3,66 & 2,00 & $\downarrow 5$ \\
\hline 27 & Sunstone Metals & Sweden & & 3,03 & 2,00 & $\downarrow 2$ \\
\hline 28 & Skaland Graphite & Norway & & 3,39 & 1,67 & $\downarrow 5$ \\
\hline 29 & DEA Norge & Norway & & 7,50 & 1,00 & $\downarrow 21$ \\
\hline 30 & $\begin{array}{l}\text { Nenetskaya } \\
\text { Neftyanaya }\end{array}$ & Russia & & 6,84 & 0,00 & $\downarrow 18$ \\
\hline
\end{tabular}

\section{Results and discussion}

The authors analyze the dynamics of the indicators calculated in the indices of previous years (Table 1).

The Polar Index used in this study, through its Integrated Corporate Sustainability Index, measures their success in key indicators: economy, social and environmental (including industrial safety). Consideration of the index in dynamics shows which companies are developing in the right direction and introducing, among other things, positive social and environmental technologies - this will be reflected in the growth of the index or in maintaining it at a high level. For example, the Integrated Corporate
Sustainability Index of Lukoil varied from 0.909 in 2018, to 0.801 in 2019 and to 0.906 in 2020, and the Integrated Corporate Sustainability Index of Rosneft in these years was $0.893,0.851$ and 0.912 , respectively [ $1,2,6]$. From this example, it can be seen that these Russian companies reduced their financial, social and environmental performance in 2019 compared to 2018 , but made up to some extent for the current year 2020 and are generally held at the top of the Polar Index. The report makes it clear that domestic companies are doing well not only through financial success but also through large-scale environmental programs, including the transition to "the best available technologies (BAT) within the framework of the Federal Project No. 11 of the national project "Ecology". 
Given climate change and growing concerns about energy security, global markets need access to clean and reliable fuels. Natural gas is a net source of hydrogen, producing energy in fuel cells with minimal emissions, and is considered essential for the transition to a sustainable energy future. It can thus be seen as a link to a renewable energy economy [2]. The process of using natural gas for electricity generation results in

Most Russian large companies, due to Soviet traditions and lack of experience in competitive markets, demonstrate elements of monopolistic thinking. Nevertheless, state-owned enterprises are willing to collaborate in the Arctic to share high technological and economic risks, and to create broader partnership networks as part of their global business strategies. In general, the analysis of the performance of companies in the Barents Polar Index rating for the period from 2018 to 2020 shows the need for companies to pay more attention to environmental aspects of sustainability, due to the special value of Arctic nature and the importance of the Arctic zone to the world. On the contrary, as shown in the above studies, at the international level, environmental aspects of sustainability prevail over economic ones.

In order to increase sustainability, mining and processing companies are actively trying to minimize their waste and improve material efficiency by developing new products from their by-products, production residues and wastes.

In the case of the Russian Arctic, there is considerable scope for the formation of industrialsymbiotic networks. Thus, to date, the Russian Federation and the Commonwealth of Independent States, as well as other former socialist countries, have no examples of successful industrial-symbiotic interactions, and only a study based on counter-factual analysis of the Kola mining community is known from unsuccessful attempts, Industrial symbiosis model never implemented [5].

The long-term sustainability of the extractive sector may depend to a large extent on innovative solutions to energy intensity and carbon dioxide (CO2) management. The authors are invited to consider in more detail the possibility of setting up an industrial symbiotic network for extractive and processing industries.

According to the authors, there is a need for largescale «carbon solutions" that can be used by several energy-intensive and carbon-intensive industries in relative proximity to each other. In particular, it is proposed to investigate the possibility of placing a mineral carbonization installation as a carbon sink at the centre of a mineral-energy complex in order to form an industrial symbiosis. Thus, a few resourceintensive industries could be synergistically integrated to create a complex of energy and mineral products with low net $\mathrm{CO} 2$ emissions. significantly lower greenhouse gas emissions compared to using coal as a fuel on a megawatt hour basis [2]. A US study suggests that replacing coal-fired power plants with natural gas-fired power plants could reduce greenhouse gas emissions by $22 \%$ [3]. The largest LNG producer and supplier in Russia is Novatek with its three largest projects Yamal LNG, Arctic LNG-2, and Obskiy LNG.

\section{Conclusion}

The proposal and promotion of the concept of sustainable development are to change the economic development regime in the regions (especially in regions with complex environmental situations or fragile ecosystems, as in the Arctic zone of the Russian Federation), to raise awareness of available and produced resources from industrial cycles and environmental protection. It will also transform highly polluting enterprises in each region into environmentally friendly ones, promote the modernization of production methods in enterprises, realize the transformation and enhance sustainable development for the economy of each region, and, finally, implement the comprehensive and sustainable development of the Russian economy.

At present, while it is difficult to measure the real performance of companies, especially in terms of their compliance with environmental and social promises, the rating provides a comprehensive view of actual public commitments and institutional arrangements of companies. The more companies formally and publicly recognize the need for greater sustainability, the greater the pressure on other companies and, consequently, the stronger the basis for establishing business norms.

With regard to the analysis of industrial symbiosis, many different indicators have been proposed to date, while a clear map of the available tools is still lacking [8]. There was an obvious imbalance in the case studies analyzed, as environmental impacts of all aspects of sustainability were the most frequently analyzed and quantified, followed by economic and social indicators.

It is proposed to classify indicators in relation to industrially symbiotic interactions in order to answer three main questions: which indicators should be selected for analysis, in relation to what and how to measure them. This contributes to a clearer understanding of the available metrics in terms of purpose, context and methodology.

The present study provides a perspective for future research. 1) Indicators measuring the social benefits of industrial-symbiotic interactions should be developed. 2) New indicators or methods to identify potential, as well as an analysis of the current interactions in the concept of industrial symbiosis, which will allow the quantification of the impact of the three dimensions of sustainability: environmental, economic and social. Although the current Polar Index concept covers these three dimensions, it does not aim at industrial symbiosis. In addition, the coverage of environmental, economic and social components entails some 
difficulties, such as the integration of qualitative and quantitative indicators into the same assessment framework [7].

Thus, new research is needed to overcome these barriers and to identify specific indicators for industrial symbiosis that will measure the overall impact of these practices on firms, the environment and society and compare industrial symbiosis in different realities, that is, different characteristics of the network, taking into account the characteristics of the region in which it develops.

\section{References}

1. S. M. Nikonorov, K. V. Papenov, Ekonomika ustojchivogo razvitija, 287-298 (2017)

2. B Shively and J Ferrare Handbook on the Physics and Chemistry of Rare Earths (Enerdynamics: Laporte, CO, USA, 2011)

3. MIT Energy Initiative 2011 the Future of Natural Gas Retrieved from: http://energy.mit.edu/research/future-natural-

\section{gas/}

4. S. M. Nikonorov, K. V. Papenov, A. V. Lebedev et al 2019 Polar index of the Barents region. Province and Company Sustainability Ratings (Expert Center for Project Development of the Arctic "PORA», 2019)

5. E. E. Utkina Vestnik of the Plekhanov Russian University of Economics 17 (5) 26-41, (2020)

6. T. Domenech, R. Bleischwitz, A. Doranova, D. Panayotopoulos and L. Roman Resources, Conservation \& Recycling, 141, 76-98, (2019)

7. S. Schoubroeck, M. Dael, S. Passel, R. Malina Renewable and Sustainable Energy Reviews 94, 115-126, (2018) 